University of Nebraska - Lincoln

DigitalCommons@University of Nebraska - Lincoln

Agronomy \& Horticulture - Faculty Publications

Agronomy and Horticulture Department

2004

\title{
Windbreaks in North American Agricultural Systems
}

James R. Brandle

University of Nebraska-Lincoln, jbrandle1@unl.edu

Laurie Hodges

University of Nebraska-Lincoln, lhodges1@unl.edu

Xinhua H. Zhou

University of Nebraska-Lincoln, xzhou2@unl.edu

Follow this and additional works at: https://digitalcommons.unl.edu/agronomyfacpub

Part of the Plant Sciences Commons

Brandle, James R.; Hodges, Laurie; and Zhou, Xinhua H., "Windbreaks in North American Agricultural Systems" (2004). Agronomy \& Horticulture -- Faculty Publications. 389.

https://digitalcommons.unl.edu/agronomyfacpub/389

This Article is brought to you for free and open access by the Agronomy and Horticulture Department at DigitalCommons@University of Nebraska - Lincoln. It has been accepted for inclusion in Agronomy \& Horticulture -Faculty Publications by an authorized administrator of DigitalCommons@University of Nebraska - Lincoln. 


\title{
Windbreaks in North American Agricultural Systems
}

\author{
James R. Brandle ${ }^{1, *}$, Laurie Hodges ${ }^{2}$ and Xinhua H. Zhou ${ }^{1}$
}

${ }^{1}$ School of Natural Resources, University of Nebraska-Lincoln, Lincoln, Nebraska, USA; ${ }^{2}$ Department of Agronomy and Horticulture, University of Nebraska-Lincoln, Lincoln, Nebraska, USA; *Author for correspondence: e-mail: jbrandle1@unl.edu

Key words: Crop production, Microclimate, Shelterbelt benefits, Shelterbelt structure, Wind protection

\begin{abstract}
Windbreaks are a major component of successful agricultural systems throughout the world. The focus of this chapter is on temperate-zone, commercial, agricultural systems in North America, where windbreaks contribute to both producer profitability and environmental quality by increasing crop production while simultaneously reducing the level of off-farm inputs. They help control erosion and blowing snow, improve animal health and survival under winter conditions, reduce energy consumption of the farmstead unit, and enhance habitat diversity, providing refuges for predatory birds and insects. On a larger landscape scale windbreaks provide habitat for various types of wildlife and have the potential to contribute significant benefits to the carbon balance equation, easing the economic burdens associated with climate change. For a windbreak to function properly, it must be designed with the needs of the landowner in mind. The ability of a windbreak to meet a specific need is determined by its structure: both external structure, width, height, shape, and orientation as well as the internal structure; the amount and arrangement of the branches, leaves, and stems of the trees or shrubs in the windbreak. In response to windbreak structure, wind flow in the vicinity of a windbreak is altered and the microclimate in sheltered areas is changed; temperatures tend to be slightly higher and evaporation is reduced. These types of changes in microclimate can be utilized to enhance agricultural sustainability and profitability. While specific mechanisms of the shelter response remain unclear and are topics for further research, the two biggest challenges we face are: developing a better understanding of why producers are reluctant to adopt windbreak technology and defining the role of woody plants in the agricultural landscape.
\end{abstract}

\section{Introduction}

Windbreaks or shelterbelts are barriers used to reduce wind speed. Usually consisting of trees and shrubs, they may be composed of perennial or annual crops, grasses, wooden fences, or other materials. Throughout history they have been used to protect homes, crops and livestock, control wind erosion and blowing snow, provide habitat for wildlife, and enhance the agricultural landscape.

Windbreaks have their origins in the mid-1400s when the Scottish Parliament urged the planting of tree belts to protect agricultural production (Droze 1977). From these beginnings, shelterbelts have been used extensively throughout the world (Caborn 1971; Grace 1977;
Brandle et al. 1988; Cleugh et al. 2002;) to provide protection from the wind. As settlement in the United States moved west into the grasslands, homesteaders planted trees to protect their homes, farms, and ranches. In the 1930s, in response to the Dust Bowl conditions, the U.S. Congress authorized the Prairie States Forestry Project to plant windbreaks (Droze 1977). In northern China, extensive plantings of shelterbelts and forest blocks were initiated in the 1950s to counter eroding agricultural conditions. Today the area is extensively protected, and studies have documented a modification in the regional climate (Zhao et al. 1995). Windbreak programs also have been established in Australia (Burke 1998), Canada (Kort 1988), New Zealand (Sturrock 1984), Russia (Konstantinov and Struzer 
Table 1. Wind speed reductions in shelter at various distances windward and leeward of shelterbelts with different optical densities in Midwestern United States ${ }^{\mathrm{a}}$.

\begin{tabular}{|c|c|c|c|c|c|c|c|c|c|c|}
\hline \multirow{3}{*}{ Type of windbreak } & \multirow{3}{*}{ Optical density } & \multicolumn{9}{|c|}{ Percent of open wind speed at various distances } \\
\hline & & \multicolumn{3}{|c|}{ Windward } & \multicolumn{6}{|c|}{ Leeward } \\
\hline & & $-25 \mathrm{H}$ & $-3 \mathrm{H}$ & $-1 \mathrm{H}$ & $5 \mathrm{H}$ & $10 \mathrm{H}$ & $15 \mathrm{H}$ & $20 \mathrm{H}$ & $25 \mathrm{H}$ & $30 \mathrm{H}$ \\
\hline Single row deciduous & $25-30$ & 100 & 97 & 85 & 50 & 65 & 80 & 85 & 95 & 100 \\
\hline Single row conifer & $40-60$ & 100 & 96 & 84 & 30 & 50 & 60 & 75 & 85 & 95 \\
\hline Multi-row conifer & $60-80$ & 100 & 91 & 75 & 25 & 35 & 65 & 85 & 90 & 95 \\
\hline Solid wall & 100 & 100 & 95 & 70 & 25 & 70 & 90 & 95 & 100 & 100 \\
\hline
\end{tabular}

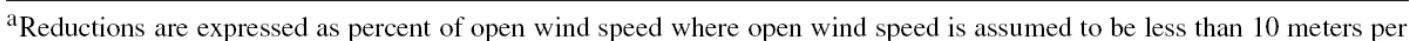
second and distance from the windbreak is expressed in terms of windbreak height $(\mathrm{H})$.

1965), South America (Luis and Bloomberg 2002), and several developing countries (Nair 1993). The focus of this chapter, however, is on windbreaks in the context of commercial, mechanized agriculture in the temperate zone, especially in North America.

The goal of this review is to provide a summary of practical information for those wishing to understand how windbreaks work and how they may be integrated into sustainable agricultural production systems. It is divided into three main sections: i) how windbreaks work, ii) how organisms respond to wind protection including the benefits of wind protection, and iii) the overall role of windbreaks in the sustainable agricultural landscape. The reader is referred to recent reviews by Nuberg (1998), Brandle et al. (2000), and Cleugh et al. (2002) for more details.

\section{How Windbreaks Work}

\section{Wind Flow in the Environment}

Wind is air in motion. It is caused by the differential heating of the earth's surface resulting in differences in pressure and is influenced by Coriolis forces caused by the earth's rotation. On a global scale, atmospheric circulation drives our daily weather patterns. On a microscale, there is a very thin layer of air (several millimeters or less) next to any surface within which transfer processes are controlled by the process of diffusion across the boundary layer. Between these two scales are the surface winds. They move in both vertical and horizontal directions and are affected by the surfaces they encounter. Surface winds extend 50 to 100 meters above the earth's surface and are dominated by strong mixing or turbulence (Grace 1981). These surface winds influence wind erosion, crop growth and development, animal health, and the general farm or ranch environment. They are also the winds affected by shelterbelts.

Although surface winds can be quite variable and the flows highly turbulent, the main component of the wind moves parallel to the ground. Wind speed at the soil surface approaches zero due to the frictional drag of the surface. The amount of drag is a function of the type of surface. In the case of vegetation, the height, uniformity, and flexibility of that vegetation determines the amount of frictional drag exerted on wind flow (Lowry 1967). A rough surface (e.g., wheat stubble) has greater frictional drag, slower wind speeds, and greater turbulence near the surface than a relatively smooth surface (e.g., mown grass). A windbreak increases surface roughness and, when properly designed, provides large areas of reduced wind speed useful for agriculture.

\section{Wind Flow Across a Barrier}

A windbreak is a barrier placed on the land surface that obstructs the wind flow and alters flow patterns both up-wind of the barrier (windward) and downwind of the barrier (leeward). As wind approaches a windbreak, a portion of the air passes through the barrier. The remaining air flows around the ends of the barrier or is forced up and over the barrier. As the air moves around or over the barrier, the streamlines of air are compressed (van Eimern et al. 1964). This upward alteration of flow begins at some distance windward of the windbreak and creates a region of reduced wind speed on the windward side. This protected area extends for a distance of $2 \mathrm{H}$ to $5 \mathrm{H}$, where $\mathrm{H}$ is the height of the barrier. A much larger region of reduced wind speed is created in the lee of the barrier. This region typically extends for a distance of $10 \mathrm{H}$ to $30 \mathrm{H}$ (Wang and Takle 1995). Some wind speed reduc- 


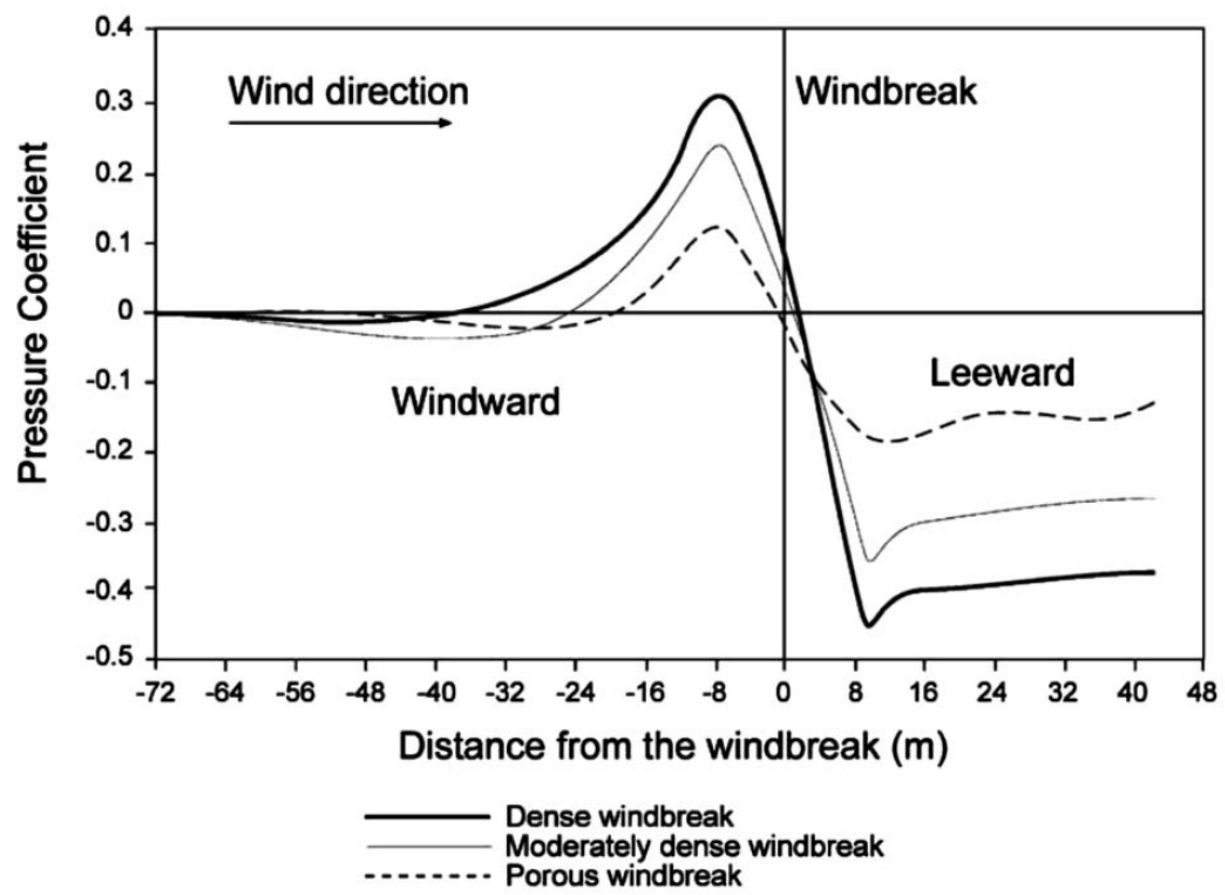

Figure 1. Changes in the pressure coefficient at ground level windward and leeward of three windbreaks with different levels of optical density. Distances from the leeward edge of the windbreak are given as positive distances and as negative distances in the windward direction.

tions extend as far as $60 \mathrm{H}$ to the lee (Caborn 1957), but it is unlikely that small reductions at these distances have significant microclimatic or biological impacts (Table 1).

Pressure on the ground is increased as the wind approaches the barrier and reaches a maximum at the windward edge of the barrier (Figure 1). Pressure drops as the wind passes through the barrier, reaching a minimum just to the lee. Pressure gradually increases returning to the original condition at or beyond $10 \mathrm{H}$. The magnitude of the pressure difference between the windward and leeward sides of the windbreak is one factor determining the flow modification of the barrier and is a function of windbreak structure (Takle et al. 1997).

\section{Windbreak Structure}

The effectiveness of a windbreak is determined partially by its external structure, which is characterized by height, length, orientation, continuity, width, and cross-sectional shape. It is determined also by its internal structure, which is a function of the amount and distribution of the solid and open portions, the vegetative surface area, and the shape of individual plant elements (Figure 2).

\section{External Structure}

Windbreak height $(\mathrm{H})$ is the most important factor determining the extent of wind protection. Distance from the windbreak is usually expressed in terms of windbreak height and is normally measured from the center of the outer row of the windbreak along a line parallel to the direction of the wind. The length of the windbreak should be at least ten times the height in order to reduce the effects of wind flow around the ends of the windbreak. Together, they determine the total area protected. Windbreaks are most efficient when they are oriented perpendicular to the problem winds. As the angle of the approaching wind becomes more oblique, the size and location of the protected zone decrease (Wang and Takle 1996a). The continuity of a windbreak also influences its efficiency: a gap or opening concentrates wind flow through the opening, creating a zone leeward of the gap in which wind speeds exceed open field wind velocities. Windbreak width influences the effectiveness of a windbreak through its influence on density (Heisler and DeWalle 1988). Traditionally this meant the adding of additional tree rows; thus, as more rows were added, density increased. More recently, researchers have distinguished between optical density, the amount of solid material appearing in a two dimensional pho- 


\section{External structure}

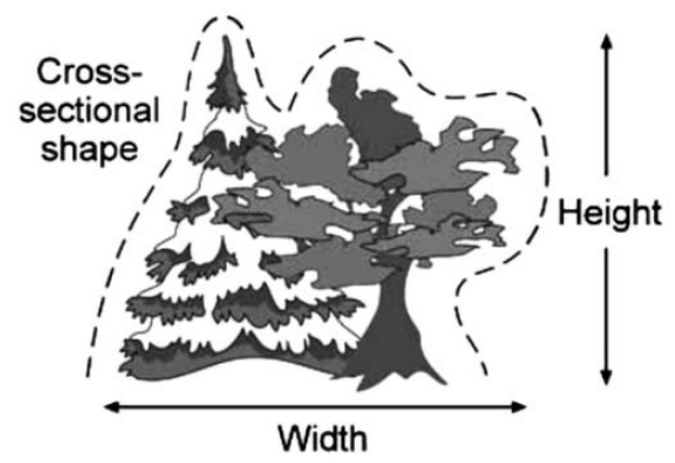

\section{Internal structure}

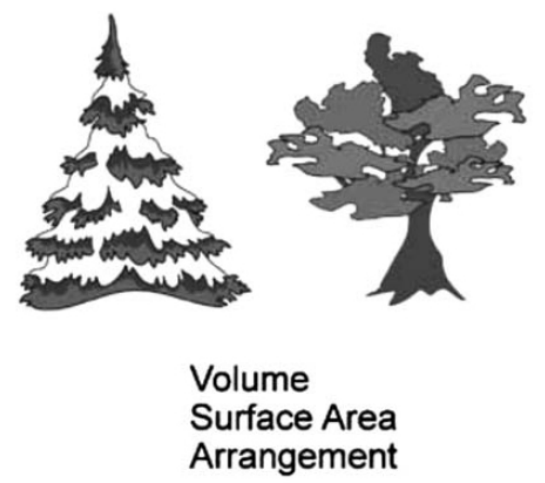

Figure 2. Illustration of the external structure components of a two row mixed windbreak. Internal structure consists of the volumes and surface areas of the individual components, leaves or needles, branches and trunk. The shape of individual elements and the arrangement of the elements within the windbreak are also components of the internal structure.

tograph, and aerodynamic density which has been defined as the amount of surface area per unit volume. This change is justified in that the wind flows not in a straight line, but around or across all of the vegetative elements in the windbreak. Research using numerical simulation methods suggests that aerodynamic density is one of the critical components of internal structure (Wang and Takle 1996b). Early work (van Eimern et al. 1964) indicated that the cross-sectional shape influences the magnitude and extent of wind speed reductions in the sheltered zone. Again, more recent research using numerical simulation models suggests that the overall arrangement of the solid and open portions of the windbreak may have significant influence on wind flow patterns. These issues are discussed in the next section.

\section{Internal Structure}

Historically the internal structure of a shelterbelt was described by either density (the amount of solid material), or porosity (the amount of open spaces) (Caborn 1957). Now, the focus is on defining the aerodynamic structure of a windbreak in three dimensions (Zhou et al. 2002). These descriptions of internal structure include the amount and distribution of the solid elements and open spaces, recognizing both volume and surface area, as well as the geometric shape of individual vegetative elements (Zhou et al. 2004). Using these parameters, the effect of shelterbelt structure on the flow fields surrounding the shelterbelt are being simulated with numerical modeling and verified under field conditions. Preliminary assessments (Brandle, Takle, Zhou unpublished data) indicate that optical density overestimates aerodynamic density, especially at higher densities. For most applications, the consequences of overestimation appear to be minimal.

\section{Microclimate Changes}

Windbreaks reduce wind speed in the sheltered zone. As a result of wind speed reduction and changes in turbulent transfer rates, the microclimate in the sheltered zone is altered (McNaughton 1988; Cleugh 2002; Cleugh and Hughes 2002). The magnitude of microclimate changes for a given windbreak varies within the protected zone. It depends on the existing atmospheric conditions, the windbreak's structure and orientation, the time of day, and the height above the ground at which measurements are made.

\section{Radiation}

On a regional scale, shelterbelts have minimal influence on the direct distribution of incoming radiation; however, they do influence radiant flux density, or the amount of energy per unit surface area per unit time, in the area immediately adjacent to the windbreak. Solar radiant flux density is influenced by sun angle, which is a function of location, season, and time of day, and by windbreak height, density, and orientation. Likewise, at any given location, the extent of the shaded zone is dependent on time of the day, season of the year, and height of the windbreak. During portions of the day, radiation is reflected off windbreak surfaces facing the sun, increasing radiant flux density immediately adjacent to the windbreak. 


\section{Air Temperature}

In temperate regions, daytime temperatures within $8 \mathrm{H}$ of a medium-dense barrier tend to be several degrees warmer than temperatures in the open due to the reduction in turbulent mixing. In tropical or semitropical regions, the magnitude of temperature effects is increased and may limit plant growth, especially in regions of limited moisture availability. In temperate regions, temperature effects appear to be greater early in the growing season. Between 8 and $24 \mathrm{H}$, daytime turbulence increases and air temperatures tend to be several degrees cooler than for unsheltered areas (McNaughton 1988). Nighttime temperatures near the ground, or within $1 \mathrm{~m}$, are generally $1^{\circ} \mathrm{C}$ to $2^{\circ} \mathrm{C}$ warmer in the protected zone, which is up to $30 \mathrm{H}$, than in the exposed areas. In contrast, temperatures $2 \mathrm{~m}$ above the surface tend to be slightly cooler. On very calm nights, temperature inversions may occur and protected areas may be several degrees cooler at the surface than exposed areas (Argete and Wilson 1989).

The largest impact of increased air temperature may be an increase in the rate of accumulation of heat units. This provides several benefits to the producer. Crops grown in sheltered areas mature more quickly than unsheltered crops. For vegetable crops, this may provide a marketing advantage and result in a premium price for the product. For grain crops, the increase in the rate of development may mean that critical stages of growth occur earlier in the season when periods of water stress may be less likely. An increase in heat units at the beginning or end of the season may allow greater flexibility in selecting crop varieties.

\section{Soil Temperature}

Average soil temperatures in shelter are slightly warmer than in unprotected areas (McNaughton 1988). In most cases this is due to the reduction in heat transfer away from the surface. In areas within the shadow of a windbreak, soil temperatures are lower due to shading of the surface. The magnitude of this effect is dependent on the time of day, height of the barrier, and the angle of the sun, which affects the size and duration of the shaded area. In areas receiving reflected radiation from the windbreak, soil temperatures may be higher due to the added radiation load. Again, it appears that these differences are greatest early in the season in temperate regions (Caborn 1957).
Frost

On clear, calm nights, infrared radiation emission by soil and vegetation surfaces is unimpeded. Under these conditions surfaces may cool rapidly resulting in decreased air temperature near the surface. When this temperature reaches the dew point, condensation forms on surfaces. If temperatures are below freezing, the condensation freezes resulting in a radiation frost. Radiation frosts are most likely under very calm conditions when strong temperature inversions may occur. In contrast, advection frosts are generally associated with large-scale, cold air masses. Strong winds are typically associated with the passage of the front and, while the radiative process contributes to heat loss, temperature inversions do not occur. Shelterbelts may offer some protection against advective frosts when episodes are of short duration and when windward temperatures are just below $0^{\circ} \mathrm{C}$. In sheltered areas, wind speed is reduced resulting in reduced turbulent transfer coefficients, or less mixing of the warm air near the surface with the colder air of the front, and reduced heat loss from the sheltered area (Brandle et al. 2000).

\section{Precipitation}

Rainfall over most of the sheltered zone is unaffected except in the area immediately adjacent to the windbreak. These areas may receive slightly more or less than the open field depending on wind direction and intensity of rainfall. On the leeward side there may be a small rain shadow where the amount of precipitation reaching the surface may be slightly reduced. The converse is true on the windward side, as the windbreak may function as a barrier and lead to slightly higher levels of measured precipitation at or near the base of the trees due to increased stemflow or dripping from the canopy.

In contrast, the distribution of snow is greatly influenced by the presence of a windbreak and can be manipulated by managing windbreak density (Scholten 1988; Shaw 1988). A dense windbreak (>60\% density) will lead to relatively short, deep snow drifts on the leeward side, while a more porous barrier ( $35 \%$ density) will provide a long, relatively shallow drift to the lee (Figure 3). In both cases, the distribution of snow and the resulting soil moisture will affect the microclimate of the site. In the case of field windbreaks, a more uniform distribution of snow may provide moisture for 


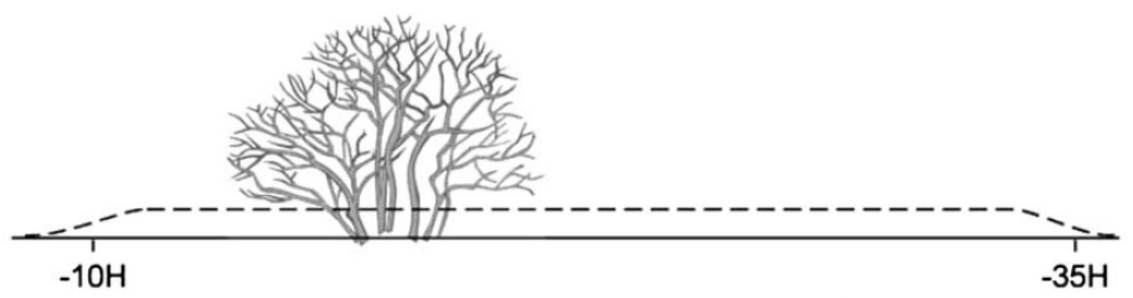

Single row deciduous tree: $\mathrm{H}=20$ feet; Density $=25$ to $35 \%$

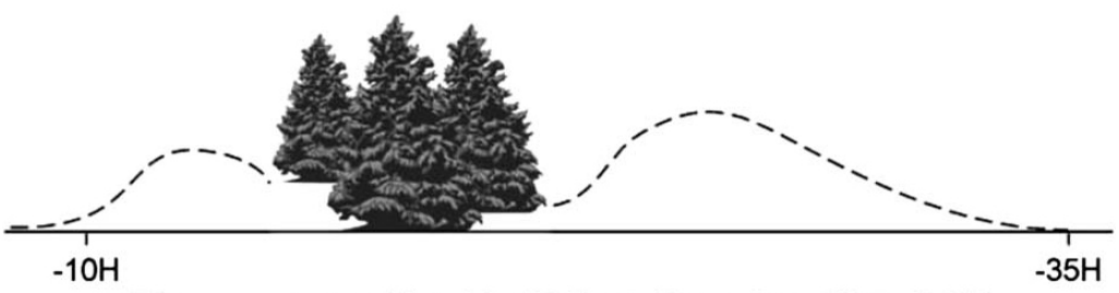

Three row conifer: $\mathrm{H}=20$ feet; Density=60 to $80 \%$

Figure 3. Snow distribution as influenced by a very porous windbreak and a very dense windbreak. The porous windbreak is used to distribute snow across a field while a dense windbreak is used to collect snow in a relatively narrow deep drift.

significant increases in crop yield. This is especially true in more northern areas where snowfall makes up a significant portion of the annual precipitation. In addition, fall planted crops insulated by a blanket of snow are protected against desiccation by cold, dry winter winds (Brandle et al. 1984).

\section{Humidity}

Humidity, or the water vapor content of the air, is related to its role in the energy balance of the system. Decreases in turbulent mixing reduce the amount of water vapor transported away from surfaces in the sheltered area. As a result, humidity and vapor pressure gradients in shelter are generally greater both during the day and at night (McNaughton 1988). And, because water vapor is a strong absorber of infrared radiation, higher humidity levels in shelter tend to protect the crop from radiative heat losses, reducing the potential for frost.

\section{Evaporation}

Evaporation from bare soil is reduced in shelter due to wind speed reductions and the reduction in transfer of water vapor away from the surface. In most cases this is an advantage, conserving soil moisture for plant growth. Evaporation from leaf surfaces is also reduced in shelter, and, in rare cases, may contribute to a higher incidence of disease. Combined with lower nighttime temperatures in shelter, high humidity levels may cause more dew formation. In these cases, the added humidity and reduced evaporation in shelter may increase the possibility of disease. However, when situations do occur where very dense windbreaks in combination with high humidity, rainfall, or irrigation may contribute to abnormally high humidity levels in sheltered areas, reducing windbreak density will increase windflow, reducing humidity and the potential for disease (Hodges and Brandle 1996).

\section{Response to Wind Protection}

\section{Response of Plants to Shelter}

The effect of wind on plants has been reviewed extensively (Grace 1988; Coutts and Grace 1995; Miller et al. 1995). Both photosynthesis and transpiration are driven in part by environmental conditions, particularly those within the leaf and canopy boundary layers of the plant. As shelter modifies micro-environment, it impacts plant productivity.

One useful concept explaining how plants respond to shelter is that of coupling. Monteith (1981) defines coupling as the capacity of exchanging energy, momentum, or mass between two systems. Exchange processes between single leaves and the atmosphere or between plant canopies and the atmosphere are controlled by the gradients of temperature, humidity, and $\mathrm{CO}_{2}$ that exist in the immediate environment above the leaf or canopy. When these gradients are modified by shelter, plant processes within the sheltered zone may 
become less strongly coupled from the atmosphere above the canopy resulting in a build up of heat, moisture, and $\mathrm{CO}_{2}$ near the surface (Grace 1981; McNaughton 1988).

Plant temperature differences between sheltered and exposed sites are relatively small, on the order of $1^{\circ} \mathrm{C}$ to $3^{\circ} \mathrm{C}$. In the sheltered zone, where the rate of heat transfer from a plant is reduced by decreased vertical temperature gradients, a slight increase in temperature can be an advantage, especially in cooler regions where even a small increase in plant temperature may have substantial positive effects on the rate of cell division and expansion and other phenological patterns (Grace 1988; van Gardingen and Grace 1991). Lower night temperatures in shelter may reduce the rate of respiration, which may result in higher rates of net photosynthesis and more growth. Indeed, there are many examples of sheltered plants being taller and having more extensive leaf areas (Rosenberg 1966; Ogbuehi and Brandle 1982). Higher soil temperatures in the sheltered zone may result in more rapid crop emergence and establishment, especially for crops with high heatunit-accumulation requirement for germination and establishment (Drew 1982). In contrast, temperatures above the optimum for plant development may lead to periods of water stress if the plant is unable to adjust to the higher demands for moisture.

The overall influence of shelter on plant water relations is extremely complex and linked to both the temperature and wind speed conditions found in shelter. Until recently, the major effect of shelter and its influence on crop growth and yield was assumed to be due primarily to soil moisture conservation and a reduction in water stress of sheltered plants (Caborn 1957; Grace 1988). There is little question that evaporation rates are reduced in shelter (McNaughton 1988); however, the effect on plant water status is less clear. According to Grace (1988), transpiration rates may increase, decrease, or remain unaffected by shelter depending on wind speed, atmospheric resistance, and saturation vapor pressure deficit. Davis and Norman (1988) suggested that under some conditions, sheltered plants made more efficient use of available water. Monteith (1993) suggested that water use efficiency in shelter was unlikely to increase except when there was a significant decrease in saturation vapor pressure deficit. Indeed, the increase of humidity in sheltered areas would contribute to a decrease in saturation vapor pressure deficit and thus an increase in water use effi- ciency. However, sheltered plants tend to be taller and have larger leaf areas. Given an increase in biomass, sheltered plants have a greater demand for water and under conditions of limited soil moisture or high temperature may actually suffer greater water stress than exposed plants (Grace 1988). Overall, shelter improves water conservation and allows the crop to make better use of available water over the course of a growing season. The magnitude of this response depends on the crop, stage of development, and environmental conditions.

The complex nature of crop water relations in shelter was demonstrated again in the recently completed Australian National Windbreak Program (Cleugh et al. 2002). Results from the program indicated generally larger plants in shelter but very mixed and frequently negative results in terms of yield response of common Australian crops. Some of these results were explained by the extreme and variable climate conditions of many Australian crop production regions and some by soils with very low soil water holding capacity. Variable precipitation patterns resulted in a shortage of moisture late in the growing season. Water holding capacity of the soil was inadequate and failed to supply sufficient water to the larger plants found in shelter resulting in reduced yields. The Australian experience clearly demonstrates that we still have much to learn on how windbreaks influence plant water use (Hall et al. 2002; Nuberg and Mylius 2002; Nuberg et al. 2002; Sudmeyer and Scott 2002).

\section{Growth and Development Response of Plants to Shelter}

As a result of favorable microclimate and the resulting physiological changes, the rate of growth and development of sheltered plants may increase. Vegetative growth is generally increased in sheltered environments (Kort 1988). The increase in the rate of accumulation of heat units in shelter contributes to earlier maturity of many crops and the ability to reach the early market with many of these perishable crops can mean sizable economic returns to producers (Brandle et al. 1995).

Wind influences plant growth directly by the mechanical manipulation of plant parts (Miller et al. 1995). This movement may increase the radial enlargement of the stem, increase leaf thickness, reduce stem elongation and leaf size (Grace 1988), and affect cellular composition (Armbrust 1982). On the whole-plant level, it 
appears that the interaction of ethylene and auxin (Biddington 1986) as well as possible inhibition of auxin transport (Mitchell 1977) are involved. The threshold wind speed and duration for these types of direct responses appears to be very low, perhaps as low as 1 $\mathrm{m} / \mathrm{s}$ for less than one minute. As a result, these types of responses may be more indicative of a no wind situation than an indicator of various wind speed differences found in sheltered and non-sheltered conditions (Miller et al. 1995).

Wind can cause direct physical damage to plants through abrasion and leaf tearing (Miller et al. 1995). As tissue surfaces rub against each other, the epicuticular waxes on the surfaces are abraded, increasing cuticular conductance and water loss (Pitcairn et al. 1986; van Gardingen and Grace 1991). Tearing is common on leaves that are larger, damaged by insects, or subjected to high wind speeds. Wind contributes to the abrasion of plant surfaces by wind blown particles (usually soil), often referred to as sandblasting. The extent of injury depends on wind speed and degree of turbulence, amount and type of abrasive material in the air stream, duration of exposure, plant species and its stage of development, and microclimatic conditions (Skidmore 1966). All three of these - abrasion, leaf tearing, and sandblasting - damage plant surfaces and can lead to uncontrolled water loss from the plant (Miller et al. 1995).

Plant lodging is another direct mechanical injury caused by wind. It takes two forms: stem lodging, where the lower internode permanently bends or breaks; and root lodging, where the soil or roots supporting the stem fail. Stem lodging is most common as crops approach maturity, while root lodging is more common on wet soils and during grain filling periods (Easson et al. 1993; Miller et al. 1995). In both cases, heavy rainfall tends to increase the potential for lodging. Medium dense shelterbelts tend to reduce crop lodging within the sheltered zone because of reduced wind speeds. As windbreak density increases, turbulence increases and the likelihood of lodging is greater.

\section{Crop Yield Response to Shelter}

While the influences of wind and shelter on individual plant processes are only partially understood, the net effect of shelter on crop yield is generally positive (Kort 1988; Brandle et al. 1992a, 2000) although the Australian experience was less conclusive (Cleugh et al. 2002). The reasons vary with crop, windbreak design, geographic location, moisture condition, soil properties and cultural practice. In 1988, Kort summarized yield responses for a number of field crops from temperate areas around the world. Average yield increases varied from $6 \%$ to $44 \%$. However, a close reading of the individual studies behind these averages indicates great variability in yield results. This is understandable because final crop yield is the culmination of a series of interacting factors present throughout the growth and development of the crop. The possible combinations of growth response and microclimate are unlimited, and the probability of a single combination and the corresponding crop response occurring on an annual basis is relatively small. As Sturrock (1984) explained, the relationship between shelter and crop response is complex and dynamic, subject to continual change as a result of changes in mesoclimate, windbreak efficiency, and growth and development of the protected crop. Again, the results from Australia illustrate how complex the issue remains.

Another factor, which may influence crop response to shelter, is crop cultivar. Almost without exception, crops have been selected and bred under exposed conditions. As a result, most common cultivars represent those selections best able to perform under exposed conditions. In order to take full advantage of the microclimate conditions created by windbreaks, a producer should select crop cultivars best suited to the microclimate conditions found in shelter. For example, using shorter, thicker-stemmed cultivars will reduce the potential for lodging while taking advantage of the favorable growing conditions found in sheltered fields.

Baldwin (1988) and Norton (1988) provide the most recent comprehensive reviews of horticultural crops and shelter. Fruits and vegetables, in general, are more sensitive to wind stress than many agronomic crops, showing loss of yield and quality at lower wind speeds. In horticultural crops, marketable yields, quality of the product, and earliness to market maturity are of primary importance (Hodges and Brandle 1996). For horticultural crops grown in sheltered conditions, the moderation of temperature extremes, warmer soil and air temperatures, and improved plant water status contributed to yield increases in total marketable yield and individual fruit weight. The moderated microclimate in shelter contributes to longer flowering periods and increased bee activity, and can result in improved fruit set and earlier maturity (Norton 1988). Wind-induced sandblasting and abrasion compound the direct effects of wind on the yield and quality of vegetable and specialty crops. As the amount of wind-blown soil, wind speed, or exposure time increases, crop survival, growth, yield, and quality decrease. Young plants tend to be more sensitive to damage. Concern for damage 
by wind-blown soil is greatest during the early spring when stand establishment coincides with seasonally high winds and large areas of exposed soil during field preparation. Another critical time is during the flowering stage when wind abrasion and abrasion by windblown soil may result in damage to or loss of buds and flowers. Vegetable producers need to be especially aware of the problems associated with wind erosion because the soil characteristics that favor vegetable production are typical of erosive soils.

\section{The Zone of Competition}

One of the most common negative comments concerning the benefits of field windbreaks is related to the impact of competition between the windbreak and the adjacent crop. There is no question that under conditions of limited moisture, competition between the windbreak and the crop has significant negative impacts on yield. Crop yields within the zone of competition may be reduced due to allelopathy, nutrient deficiency, shading, temperature, or soil moisture deficiency (Kort 1988). The degree of competition varies with crop, geographic location (Lyles et al. 1984), windbreak species, and soil or climate conditions (Sudmeyer et al. 2002).

It may be possible to reduce some forms of competition by tree-root pruning, i.e, cutting of lateral tree roots extending into the crop field. The effectiveness of the practice depends on the rooting patterns of the windbreak species, the depth of root pruning, and soil moisture levels (Rasmussen and Shapiro 1990; Hou et al. 2003; Jose et al. 2004). Under limited moisture conditions, root pruning significantly increases crop yields within the zone of competition. During wet years, the benefits are less obvious. Root pruning must be repeated every one to five years depending on tree species and local weather conditions and can have negative impacts on windbreak survival.

\section{Wind Erosion Control}

Of all the benefits of field windbreaks, wind erosion control is the most widely accepted. If wind speed is reduced, wind erosion and its impacts on both crop productivity and off-site costs are reduced (Huszar and Piper 1986; Pimental et al. 1995; Ribaudo 1986). Windblown soil can carry inoculum for bacterial and fungal diseases as well as provide potential entry points for pathogens. Controlling wind erosion may reduce the incidence and severity of crop diseases (Hodges and Brandle 1996). It is worth noting that while crop responses were mixed in the Australian studies, the benefits associated with wind erosion control were reaffirmed (Cleugh et al. 2002; Sudmeyer et al. 2002).

\section{Snow Management}

In many northern, semiarid areas, snow is a critical source of soil moisture for crop and forage production during the subsequent growing season. Greb (1980) estimated that over one-third of the snowfall in these northern areas is blown off the field. Much of this wind-blown snow is deposited in road ditches, gullies, or behind fence-rows or other obstructions (Aase and Siddoway 1976). Even more may simply evaporate (Schmidt 1972). Many factors influence snow distribution including: i) the amount and specific gravity of the snow, ii) the topography and surface conditions, iii) wind velocity and direction, and iv) the presence and characteristics of barriers to wind flow (Scholten 1988). Field windbreaks help capture the moisture available in snow by slowing the wind and distributing the snow across the field. As a result, crop yields on fields protected by field windbreaks are increased 15\% to 20\% (Brandle et al. 1984; Kort 1988). These increases are a result of increased moisture due to snow capture and the protection of the crop from wind desiccation.

\section{Integrated Pest Management and Windbreaks}

Both crop pests and their natural enemies are influenced by the presence of windbreaks (Dix et al. 1995; Burel 1996). This influence is reflected in the distribution of insects as a result of wind speed reductions in the sheltered zone (Heisler and Dix 1988; Pasek 1988) or as a function of the numerous microhabitats, including the diversity of the associated plant species (Corbett and Plant 1993; Corbett and Rosenheim 1996; Forman 1995). Windbreaks influence the distribution of both predator and prey. In narrow vegetative windbreaks or artificial windbreaks, insect distribution appears to be primarily a function of wind conditions. As windbreak structure becomes more complex, various microhabitats are created and insect populations increase in both number and diversity (Pasek 1988). Greater vegetative diversity of the edges provides numerous microhabitats for life-cycle activities and a variety of hosts, prey, pollen, and nectar sources. 


\section{Windbreak Technology at the Farm and Landscape Levels}

In this section we identify other windbreak uses and their benefits and discuss very briefly the ecological implications of windbreak technology to support the farm operation.

\section{Livestock Windbreaks}

There are many benefits of windbreaks to the successful livestock operation. As in the case of crops, the goal is to utilize the microclimate conditions created by shelter to benefit the animal production system. In the northern Great Plains of the United States, the Canadian Prairie region, and southern Australia, livestock protection is a vital part of successful operations. Livestock vary in their need for wind protection (Primault 1979). Producers in North and South Dakota, United States, report significant savings in feed costs, survival, and milk production when livestock are protected by windbreaks from winter storms (Anderson and Bird 1993). New-born lambs and freshly shorn sheep are especially sensitive to cold, wet, windy conditions (Bird 2000; Holmes and Sykes 1984) and benefit significantly from wind protection. While the literature on the effects of shelter on livestock production is not nearly as extensive as that pertaining to crop production, there does appear to be a consensus, especially among producers, that reducing wind speed in winter lowers animal stress, improves animal health, increases feed efficiency, and provides positive economic returns (Atchison and Strine 1984; Bird 2000).

As minimum daily temperatures decrease, cattle on rangeland spend less time grazing, reducing forage intake and weight gain (Adams et al. 1986). In a pair of recent studies of winter stalk grazing in east-central Nebraska (Morris et al. 1996; Jordon et al. 1997), average winter temperatures (1994-1995 and 1995-1996) were moderate and animals behaved similarly on both open and sheltered fields. However, on days with low temperatures $\left(\leq 20^{\circ} \mathrm{C}\right)$ and strong winds $(>10 \mathrm{~m} / \mathrm{s})$, cattle sought any available shelter. In particular, it was noted that cattle on the sheltered fields were grazing in the sheltered zones, while cattle on the exposed fields were lying down in low areas to reduce stress associated with the cold, windy conditions. Even so, they concluded that shelter had little effect on weight gain from winter stalk grazing during mild winters in eastcentral Nebraska.
Properly designed livestock windbreaks provide additional benefits to the livestock producer (Dronen 1988; Brandle et al. 2000). On rangeland, windbreaks located across the landscape will increase the amount of forage production on the sheltered areas (Kort 1988) and provide protection for calving against early spring snow-storms. In a Kansas study, average calving success increased $2 \%$ when cows were protected by a windbreak (Quam et al. 1994). Windbreaks can be designed to harvest snow and provide water to supplement stock ponds located in remote areas (Tabler and Johnson 1971; Jairell and Schmidt 1986, 1992). Protecting confinement systems with multi-row windbreaks can control snow drifting, enabling access to feedlots and other facilities such as grain and hay storage, and reducing costs associated with snow removal (Dronen 1984).

\section{Windbreaks and Specialty Crops}

Incorporating various nut or fruit species, woody decorative florals or other specialty crops into windbreak plantings may provide additional income for producers. A recent study in Nebraska (Josiah et al. 2004) indicated gross returns approaching $\$ 15$ per meter on the best producing species. Initial investment, labor costs and marketing expenses are high and remain the principle challenge for producers wishing to pursue these types of operations. A careful market analysis should be conducted prior to pursuing specialty crop production systems as local markets are often limited and quickly saturated leaving the producer with few options.

\section{Farmstead Windbreaks}

The basic goal of a farmstead windbreak is to provide protection to the living and working area of a farm or ranch. The greatest economic benefit is derived from reducing the amount of energy needed to heat and cool the home. The amount of savings varies with climatic conditions, (particularly wind and temperature), as well as local site conditions, home construction, and the design and condition of the windbreak. Well-designed farmstead windbreaks can cut the average energy use of a typical farm or ranch home in the northern portions of the United States and Canada by 10\% to 30\% (DeWalle and Heisler 1988).

Farmstead windbreaks improve living and working conditions by screening undesirable sights, sounds, smells, and dust from nearby agricultural activities or roads. They reduce the effects of windchill and make 
outdoor activities less stressful. Properly located farmstead windbreaks can help in snow management, reducing the time and energy involved in snow removal from farm working areas and driveways. Locating the family garden within the sheltered zone improves yield and quality, and incorporating fruit and nut production into the windbreak will add additional benefits (Wight 1988).

\section{Wildife Windbreaks}

In many agricultural areas, windbreak and riparian systems offer the only woody habitat for wildlife (Johnson and Beck 1988). In Nebraska, foresters identify wildlife as a primary reason given by landowners for the establishment of windbreaks on agricultural land. Recently, Beecher et al. (2002) reemphasized the potential role of these types of habitats in the control of crop pests in agricultural regions. Because of their linear nature, windbreaks are dominated by edge species. As the width of a windbreak increases, species diversity increases as additional microhabitats are added (Forman 1995). In a Kansas study of habitat use within agricultural settings, these linear forests were favored by hunters and contributed significantly to the local economy (Cable and Cook 1990).

\section{Windbreaks and Climate Change}

Brandle et al. (1992b) assessed the potential of windbreaks as a means of reducing atmospheric $\mathrm{CO}_{2}$ concentration. They calculated not only the direct sequestration of carbon in the growing trees but also estimated the indirect benefits to agricultural production systems due to crop and livestock protection and energy savings (See also Kort and Turnock 1999).

Windbreaks can play a significant role in adaptation strategies as agricultural producers strive to adapt to changing climates. Easterling et al. (1997) reported that windbreaks could help maintain maize (Zea mays) production in eastern Nebraska under several climate scenarios. Using a crop modeling approach, they considered temperature increases up to $5^{\circ} \mathrm{C}$, precipitation levels of $70 \%$ to $130 \%$ of normal, and wind speed changes of plus or minus $30 \%$. In all cases, sheltered crops continued to perform better than nonsheltered crops. In all but the most extreme cases, windbreaks more than compensated for the change in climate, indicating the potential value of wind protection under these conditions.

\section{Conclusion}

In the context of agroforestry practices in temperate regions, windbreaks or shelterbelts are a major component of successful agricultural systems. By increasing crop production while reducing the level of inputs, they reduce the environmental costs associated with agriculture. They help control erosion, particularly wind erosion, and contribute to the long-term health of our agricultural systems. When various species are included in the design, they can contribute directly to the production of nuts, fruits, timber, and other wood products as well as farmstead aesthetics. When used in livestock production systems, they improve animal health, improve feed efficiency, and contribute to the economic return of producers. Designed for snow management, they can capture snow for crop or livestock production.

As part of the overall agricultural enterprise, they reduce energy consumption by the farm or ranch home and improve working conditions within the farm area. When designed for snow control, they can reduce the costs of snow removal and improve access to livestock feeding areas. Windbreaks provide habitat for wildlife and a number of benefits to landowners and producers alike. The interspersion of woody wildlife habitat in agricultural areas contributes to a healthy and diverse wildlife population to the benefit of both hunters and nonhunters.

On a larger scale, windbreaks provide societal benefits both locally and regionally. Reductions in erosion not only benefit the landowner but reduce the off-site costs of erosion as well. Windbreaks have potential to assist with adapting to future changes in climate and may, in some cases, ease the economic burdens associated with this change.

The integration of windbreaks and other agroforestry practices into sustainable agricultural systems can provide many rewards. It requires, however, careful consideration of all aspects of the agricultural system, an understanding of basic ecological principles, and a working knowledge of local conditions and markets.

\section{Future Research Needs}

Even with the long history of windbreak research there remain a number of specific questions, which should be addressed. For example: $i$. What are the relationships between windbreak structure and how the windbreak functions? ii. Are there methods available 
to practitioners to determine the three-dimensional structure of a windbreak so that the landowner can manage the windbreak to meet his/her specific goal? iii. What are the mechanisms of crop and animal response to sheltered microclimate and how can we manipulate the microclimate to take advantage of the shelter we have created?

In addition to these very detailed questions, there are two very broad issues, which must be addressed. We must begin to look at the role of woody plants, whether in windbreaks, riparian systems or other woody plantings, in the context of the overall agricultural landscape. New techniques in landscape ecology must be applied to determine the overall impact of woody plants on ecosystem health and the impacts of diverse landscapes on human health. Second, while research has identified numerous benefits, both economic and environmental, the use of many conservation buffer plantings such as windbreaks or riparian forest buffers, is not wide spread. Adoption by landowners has been limited. Understanding adoption techniques and developing new ways to secure higher levels of adoption of conservation practices involving woody plants are critical to the future success of agroforestry programs.

\section{Acknowledgements}

A contribution of the University of Nebraska Agricultural Research Division, Lincoln NE, Journal Series No. 14350. This research was supported in part by funds provided through the Hatch Act and by McIntyre Stennis Forestry Research Funds.

\section{References}

Aase J.K. and Siddoway F.H. 1976. Influence of tall wheatgrass wind barriers on soil drying. Agron J 68: 627-631.

Adams D.C., Nelsen T.C., Reynolds W.L. and Knapp B.W. 1986. Winter grazing activity and forage intake of range cows in the northern Great Plains. J Anim Sci 62: 1,240-1,246.

Anderson V.L. and Bird J. 1993. Effects of shelterbelt protection on performance of feedlot steers during a North Dakota winter. 1993 Beef Production Field Day, Carrington Res. Ext. Ctr., Livestock Unit. Vol 16: 19-21. North Dakota State Univ., Fargo.

Argete J.C. and Wilson J.D. 1989. The microclimate in the centre of small square sheltered plots. Agr For Meteorol 48: 185-199.

Armbrust D.V. 1982. Physiological responses to wind and sandblast damage by grain sorghum plants. Agron J 74: 133-135.

Atchison F.D. and Strine J.H. 1984. Windbreak Protection for Beef Cattle. Kansas State University Cooperative Extension Service Publication No. L-708, Manhattan, KS.

Baldwin C.S. 1988. The influence of field windbreaks on vegetable and specialty crops. Agric Ecosyst Environ 22/23: 159-163.
Beecher N.A., Johnson R.J., Brandle J.R., Case R.M. and Young L.J. 2002. Agroecology of birds in organic and nonorganic farmland. Conserv Biol 16: 1,620-1,631.

Biddington N.L. 1986. The effects of mechanically-induced stress in plants - a review. Plant Growth Regulat 4: 103-123.

Bird P.R. 2000. Farm Forestry in Southern Australia - A Focus on Clearwood Production of Specialty Timbers. Pastoral and Veterinary Institute, Dept. Natural Resources and Environment, Victoria, Australia, 264 pp.

Brandle J.R., Hintz D.L. and Sturrock J.W. 1988. Windbreak Technology. Elsevier Science Publishers, Amsterdam, 598 pp.

Brandle J.R., Hodges L. and Stuthman J. 1995. Windbreaks and specialty crops for greater profits. pp. 81-91. In: Rietveld W.J. (ed.), Agroforestry and Sustainable Systems: Symposium Proceedings. USDA For. Serv. Gen. Tech. Rpt. RM-GTR-261.

Brandle J.R., Hodges L. and Wight B. 2000. Windbreak practices. pp. 79-118. In: Garrett H.E., Rietveld W.E. and Fisher R.F. (eds), North American agroforestry: An Integrated Science and Practice. Am. Soc. Agronomy, Madison, WI.

Brandle J.R., Johnson B.B. and Akeson T. 1992a. Field windbreaks: Are they economical? J Prod Agric 5: 393-398.

Brandle J.R., Johnson B.B. and Dearmont D.D. 1984. Windbreak economics: The case of winter wheat production in eastern Nebraska. J Soil Water Conserv 39: 339-343.

Brandle J.R., Wardle T.D. and Bratton G.F. 1992b. Opportunities to increase tree planting in shelterbelts and the potential impacts on carbon storage and conservation. pp. 157-176. In: Sampson N.R. and Hair F. (eds), Forests and Global Change, Vol. 1. Opportunities for Increasing Forest Cover. American Forests, Washington, DC.

Burel F. 1996. Hedgerows and their roles in agricultural landscapes. Critical Reviews in Plant Sciences 15(2): 169-190.

Burke S. 1998. Windbreaks. Inkata Press, Port Melbourne, Victoria, Australia.

Cable T.T. and Cook P.S. 1990. The use of windbreaks by hunters in Kansas. J Soil Water Conserv 45: 575-577.

Caborn J.M. 1957. Shelterbelts and Microclimate. Forestry Commission Bull. No. 29. Edinburgh University, Edinburgh, 135 pp.

Caborn J.M. 1971. The agronomic and biological significance of hedgerows. Outlook Agr 6: 279-284.

Cleugh H.A. 2002. Field measurements of windbreak effects on airflow, turbulent exchange and microclimates. Aust J Exp Ag 42: 665-677.

Cleugh H.A. and Hughes D.E. 2002. Impact of shelter on crop microclimates: A synthesis of results from wind tunnel and field experiments. Aust J Exp Ag 42: 679-701.

Cleugh H.A., Prinsley R., Bird P.R., Brooks S.J., Carberry P.S., Crawford M.C., Jackson T.T., Meinke H., Mylius S.J., Nuberg I.K., Sudmeyer R.A. and Wright A.J. 2002. The Australian National windbreaks program: Overview and summary of results. Aust J Exp Ag 42: 649-664.

Corbett A. and Plant R.E. 1993. Role of movement in the response of natural enemies to agroecosystem diversification: A theoretical evaluation. Environ Entomol 22(3): 519-531.

Corbett A. and Rosenheim J.A. 1996. Impact of a natural enemy overwintering refuge and its interaction with the surrounding landscape. Ecol Entomol 21: 155-164.

Coutts M.P. and Grace J. 1995. Wind and Trees. University Press, Cambridge, 485 pp.

Davis J.E. and Norman J.M. 1988. Effects of shelter on plant water use. Agric Ecosyst Environ 22/23: 393-402. 
DeWalle D.R. and Heisler G.M. 1988. Use of windbreaks for home energy conservation. Agric Ecosyst Environ 22/23: 243-260.

Dix M.E., Johnson R.J., Harrel M.O., Case R.M., Wright R.J., Hodges L, Brandle J.R., Schoenberger M.M., Sunderman N.J., Fitzmaurice R.L., Young L.J. and Hubbard K.G. 1995. Influence of trees on abundance of natural enemies of insect pests: A review. Agroforest Syst 29: 303-311.

Drew R.L.K. 1982. The effects of irrigation and of shelter from wind on emergence of carrot and cabbage seedlings. J Hort Sci 57: 215-219.

Dronen S.I. 1984. Windbreaks in the Great Plains. North J Appl For 1: 55-59.

Dronen S.I. 1988. Layout and design criteria for livestock windbreaks. Agric Ecosyst Environ 22/23: 231-240.

Droze W.H. 1977. Trees, Prairies, and People: A History of Tree Planting in the Plains States. USDA For. Serv. and Texas Woman's University Press, Denton, TX, 313 pp.

Easson D.L., White E.M. and Pickles S.J. 1993. The effects of weather, seed rate, and cultivar on lodging and yield in winter wheat. J Agric Sci 121: 145-156.

Easterling W.E., Hays C.J., Easterling M.M., and Brandle J.R. 1997. Modeling the effect of shelterbelts on maize productivity under climate change: An application of the EPIC model. Agric Ecosyst Environ 61: 163-176.

Forman R.T.T. 1995. Land Mosaics: The Ecology of Landscapes and Regions. Cambridge University Press, Cambridge, 632 pp.

Grace J. 1977. Plant Response to Wind. Academic Press, London.

Grace J. 1981. Some effects of wind on plants. pp. 31-56. In: Grace J., Ford E.D. and Jarvis P.G. (eds), Plants and their Atmospheric Environment, Blackwell Scientific Publishers, Oxford.

Grace J. 1988. Plant response to wind. Agr Ecosyst Environ 22/23: 71-88.

Greb B.W. 1980. Snowfall and its potential management in the semiaridcentralGreatPlains.USDA.Res.Sci.Ed.Admin.,Western Series No. 18. USDA, Agricultural Research, Oakland, CA.

Hall D.J.M., Sudmeyer R.A., McLernon C.K. and Short R.J. 2002. Characterization of a windbreak system on the south coast of Western Australia. 3. Soil water and hydrology. Aust J Exp Ag 42: 729-738.

Heisler G.M. and DeWalle D.R. 1988. Effects of windbreak structure on wind flow. Agric Ecosyst Environ 22/23: 41-69.

Heisler G.M. and Dix M.E. 1988. Effects of windbreaks on local distribution of airborne insects. pp. 5-12. In: Dix M.E. and Harrell M. (eds), Insects of Windbreaks and Related Plantings: Distribution, Importance, and Management. Conference Proceedings, December 6, 1988, Louisville, KY. USDA Forest Service, Gen Tech Rpt RM-204. Hodges L. and Brandle J.R. 1996. Windbreaks: An important component in a plasticulture system. HortTechnology 6(3): 177-181.

Holmes C.W. and Sykes A.R. 1984. Shelter and climatic effects on livestock. pp. 19-35. In: Sturrock J.W. (ed.). Shelter Research Needs in Relation to Primary Production: The report of the National Shelter Working Party, Wellington, New Zealand. Water Soil Misc Publ No. 59.

Hou Q., Brandle J., Hubbard K., Schoeneberger M., Nieto C. and Francis C. 2003. Alteration of soil water content consequent to root-pruning at a windbreak/crop interface in Nebraska, USA. Agroforest Syst 57: 137-147.

Huszar P.C. and Piper S.L. 1986. Estimating the off-site costs of wind erosion in New Mexico. J Soil Water Conserv 41(6):414-416.

Jairell R.L. and Schmidt R.A. 1986. Scale model tests help optimize wind protection and water improvements for livestock. pp. 159-161. In: Hintz D.L. and Brandle J.R. (eds), Proceedings International Symposium on Windbreak Technology, June 23- 27,
1986. Great Plains Agricultural Council-Forestry Committee. Publ. No. 117.

Jairell R.L. and Schmidt R.A. 1992. Harvesting snow when water levels are low. pp. 121-124. In: Shafer B. (ed.) Proceedings, 60th Western Snow Conference, April 14-16, 1992, Jackson, WY.

Johnson R.J. and Beck M.M. 1988. Influences of shelterbelts on wildlife management and biology. Agric Ecosyst Environ 22/23: 301-335.

Jordan D.J., Klopfenstein T., Brandle J. and Klemesrud M. 1997. Cornstalk grazing in protected and unprotected fields. pp. 24. In: 1997 Nebraska Beef Report, University of Nebraska, Lincoln. MP 67.

Jose S., Gellespie A.R. and Pallardy S.G. 2004. Interspecific interactions in temperate agroforestry (This volume).

Josiah S.J., St-Pierre R, Brott H. and Brandle J.R. 2004. Productive conservation: Diversifying farm enterprises by producing specialty woody products in agroforestry systems. J Sustain Agr 23: 93-108.

Konstantinov A.R. and Struzer L.R. 1965. Shelterbelts and Crop Yields. Translated from Russian by Israel Program for Scientific Translations. U.S. Department of Commerce, Clearinghouse for Federal Scientific Technical Information, Springfield, VA.

Kort J. 1988. Benefits of windbreaks to field and forage crops. Agric Ecosyst Environ 22/23: 165-190.

Kort J. and Turnock R. 1999. Carbon reservoir and biomass in Canadian prairie shelterbelts. Agroforest Syst 44: 175-186.

Lowry W.P. 1967. Weather and Life: An Introduction to Biometeorology. Academic Press, New York.

Luis P.P. and Bloomberg M. 2002. Windbreaks in southern Patagonia, Argentina: A review of research on growth models, wind speed reduction, and effects on crops. Agroforest Syst 56: 129-144.

Lyles L., Tatarko J. and Dickerson J.D. 1984. Windbreak effects on soil water and wheat yield. Trans ASAE 20: 69-72.

McNaughton K.G. 1988. Effects of windbreaks on turbulent transport and microclimate. Agr Ecosyst Environ 22/23: 17-40.

Miller J.M., Bohm M. and Cleugh H.A. 1995. Direct Mechanical Effects of Wind on Selected Crops: A Review. Centre for Environmental Mechanics, Canberra, ACT. Tech. Rpt. No. 67.

Mitchell C.A. 1977. Influence of mechanical stress on auxin stimulated growth of excised pea stem sections. Physiol Plant 41: 129-134.

Monteith J.L. 1981. Coupling of plants to the atmosphere. pp. 1- 29. In: Grace J., Ford E.D. and Jarvis P.G. (eds), Plants and their Atmospheric Environment. Blackwell Scientific Publishers, Oxford. Monteith J.L. 1993. The exchange of water and carbon by crops in a Mediterranean climate. Irrig Sci 14: 85-91.

Morris C., Klopfenstein T., Brandle J., Stock R., Shain D. and Klemesrud M. 1996. Winter calf grazing and field windbreaks. 1996 Nebraska Beef Report. University of Nebraska, Lincoln, MP 66-A: 44.

Nair P.K.R. 1993. An Introduction to Agroforestry. Kluwer, Dordrecht, The Netherlands, 499 pp.

Norton R.L. 1988. Windbreaks: Benefits to orchard and vineyard crops. Agric Ecosyst Environ 22/23: 205-213.

Nuberg I.K. 1998. Effect of shelter on temperate crops: A review to define research for Australian conditions. Agroforest Syst 41: 3-34.

Nuberg I.K. and Mylius S.J. 2002. Effect of shelter on the yield and water use of wheat. Aust J Exp Ag 42: 773-780.

Nuberg I.K., Mylius S.J., Edwards J.M. and Davey C. 2002. Windbreak research in a South Australian cropping system. Aust J Exp Ag 42: 781-795. 
Ogbuehi S.N. and Brandle J.R. 1982. Influence of windbreakshelter on soybean growth, canopy structure, and light relations. Crop Sci 22: 269-273.

Pasek J.E. 1988. Influence of wind and windbreaks on local dispersal of insects. Agric Ecosyst Environ 22/23: 539-554.

Pitcairn C.E.R., Jeffree C.E. and Grace J. 1986. Influence of polishing and abrasion on the diffusive conductance of leaf surfaces of Festuca arundinacea Schreb. Plant Cell Environ 9: 191196.

Pimental D., Harvey C., Resosudarmo P., Sinclair K., Kurz D., McNair M., Crist S., Shpritz L., Fitton L., Saffouri R. and Blair R. 1995. Environmental and economic costs of soil erosion and conservation benefits. Science 267: 1,117-1,123.

Primault B. 1979. Optimum climate for animals. pp. 182-189. In: Seemann J., Chirkov Y.I., Lomas J. and Primault B. (eds), Agrometeorology, Springer-Verlag, Berlin.

Quam V.C., Johnson L., Wight B. and Brandle J.R. 1994. Windbreaks for Livestock Production. University of Nebraska Cooperative Extension EC 94-1766-X, Lincoln, NE.

Rasmussen S.D. and Shapiro C.A. 1990. Effects of tree root-pruning adjacent to windbreaks on corn and soybeans. J Soil Water Conserv 45(5): 571-575.

Ribaudo M.O. 1986. Targeting soil conservation programs. Land Econ 62(4): 402-411.

Rosenberg N.J. 1966. Microclimate, air mixing, and physiological regulation of transpiration as influenced by wind shelter in an irrigated bean field. Agr Meteorol 3: 197-224.

Scholten H. 1988. Snow distribution on crop fields. Agric Ecosyst Environ 22/23: 363-380.

Schmidt R.A. Jr. 1972. Sublimination of wind-transported snow - a model. USDA For. Serv. Res. Pap. RM-90. Rocky Mtn. Forest and Range Exp. Stn.

Shaw D.L. 1988. The design and use of living snowfences in North America. Agr Ecosyst Environ 22/23: 351-362.

Skidmore E.L. 1966. Wind and sandblast injury to seedling green beans. Agron J 58: 311-315.

Sturrock J.W. 1984. The role of shelter in irrigation and water use. pp. 79-86. In: Sturrock J.W. (ed.), Shelter Research Needs in Relation to Primary Production: The Report of the National Shelter Working Party Ministry of Works and Development, Water and Soil Misc. Publ. No. 94, Wellington, New Zealand.
Sudmeyer R.A. and Scott P.R. 2002. Characterization of a windbreak system on the south coast of Western Australia 1. Microclimate and wind erosion. Aust J Exp Ag 42: 717-715.

Sudmeyer R.A., Hall D.J.M., Eastham J. and Adams M.A. 2002. The tree-crop interface: The effects of root pruning in southwestern Australia. Aust J Exp Ag 42: 763-772.

Tabler R.D. and Johnson K.L. 1971. Snow fences for watershed management. pp. 116-121. In: Snow and ice in relation to wildlife and recreation. Symposium Proceedings. Ames, IA, February 11-12, 1971.

Takle E.S., Wang H., Schmidt R.A., Brandle J.R. and Jairell R.L. 1997. Pressure perturbation around shelterbelts: Measurements and model results. In: 12th Symposium on Boundary Layers and Turbulence. pp. 563-564. American Meteorological Society, July 1997, Vancouver, British Columbia.

van Eimern J., Karschon R., Razumava L.A. and Robertson G.W. 1964. Windbreaks and Shelterbelts. Technical Note No. 59 (WMO-No.147.TP.70), Geneva, Switzerland.

van Gardingen P. and Grace J. 1991. Plants and wind. Adv Bot Res 18: 189-253.

Wang H. and Takle E.S. 1995. Numerical simulations of shelterbelt effects on wind direction. J Appl Meteorol 34: 2,206-2,219.

Wang H. and Takle E.S. 1996a. On shelter efficiency of shelterbelts in oblique wind. Agr For Meteorol 81: 95-117.

Wang H. and Takle E.S. 1996b. On three-dimensionality of shelterbelt structure and its influences on shelter effects. Boundary-Layer Meteorol 79: 83-105.

Webster A.J.F. 1970. Direct effects of cold weather on the energetic efficiency of beef production in different regions of Canada. Can J Anim Sci 50: 563-573.

Wight B. 1988. Farmstead windbreaks. Agr Ecosyst Environ 22/23: 261-280.

Zhao Z., Xiao L., Zhao T. and Zhang H. 1995. Windbreaks for Agriculture. China Forestry Publishing House, Beijing (In Chinese).

Zhou X.H., Brandle J.R., Takle E.S. and Mize C.W. 2002. Estimation of the three-dimensional aerodynamic structure of a green ash shelterbelt. Agr Forest Meteorol 111: 93-108.

Zhou X.H., Brandle J.R., Mize C.W. and Takle E.S. 2004. The relationship of three-dimensional structure to shelterbelt function: A theoretical hypothesis. J Crop Production (In press). 